\title{
39. THAUMASITE IN LAU BASIN BASALTIC ANDESITE, HOLE 841B ${ }^{1}$
}

\author{
Dietmar Schöps² and Peter M. Herzig ${ }^{2}$
}

\begin{abstract}
Hole 84IB was drilled in the forearc region of the Lau Basin at a water depth of $4810 \mathrm{~m}$. The hole penetrated a roughly 500 - $\mathrm{m}$-thick series of Miocene volcanic sediments with a number of basaltic to andesitic units (sills?) varying in thickness between $7 \mathrm{~cm}$ and $17 \mathrm{~m}$. The volcanics are slightly to moderately altered and contain analcite, chabazite, natrolite-thompsonite, heulandite (?), prehnite, and quartz as secondary phases. In addition, thaumasite $\left[\mathrm{Ca} 3 \mathrm{Si}(\mathrm{OH})_{6} \cdot 12 \mathrm{H}_{2} \mathrm{O}\right]\left(\mathrm{SO}_{4}\right)\left(\mathrm{CO}_{3}\right)$ was identified in the altered sequence. Sulfur isotope data of two thaumasite separates $\left(+23.5 \%\right.$ and $\left.+21.1 \% 0 \delta^{34} \mathrm{~S}\right)$ indicate a seawater origin of the sulfate sulfur. It is suggested that thaumasite is a product of low-temperature $\left(<60^{\circ} \mathrm{C}\right)$, seawater-derived $\mathrm{CaCl}_{2}$-rich fluids that were almost identical in composition to those presently circulating in the sub-seafloor.
\end{abstract}

\section{INTRODUCTION}

Thaumasite is a hydrated $\mathrm{Ca}-\mathrm{Si}$ carbonate sulfate hydroxide with the formula $\left[\mathrm{Ca}_{3} \mathrm{Si}(\mathrm{OH})_{6} \cdot 12 \mathrm{H}_{2} \mathrm{O}\right]\left(\mathrm{SO}_{4}\right)\left(\mathrm{CO}_{3}\right)$. It has a hexagonal structure and, together with ettringite $\left(\mathrm{Ca}_{6} \mathrm{Al}_{2}\left[(\mathrm{OH})_{4} / \mathrm{SO}_{4}\right]_{3} \cdot 26 \mathrm{H}_{2} \mathrm{O}\right)$ and jouravskite $\left(\mathrm{Ca}_{6} \mathrm{H}_{4}\left[\mathrm{SO}_{4} / \mathrm{CO}_{3} /\left(\mathrm{MnO}_{4}\right)^{4}\right] \mathrm{v}_{2} \cdot 28 \mathrm{H}_{2} \mathrm{O}\right)$, forms a unique mineral family.

Thaumasite was first described by Nordenskiöld (1878). Later studies identified thaumasite as a product of geothermal water interacting with basalt and tuffs (e.g., Hentschel, 1979; Heritsch, 1988). Thaumasite also occurs in the groundmass of contact metamorphic rocks, replacing calcite and/or gypsum (e.g., Larsen and Dunham, 1933), and it is a common mineral in sulfide and manganese mines where it occurs in form of hydrothermal veins (e.g., Vogt, 1938; Grubesi et al., 1986).

The first description of thaumasite in an oceanic environment is from Noack (1983), who identified thaumasite as a cement in several basaltic breccias of the Echo II borehole at the Mururoa Atoll in association with zeolites such as phillipsite, chabazite, gmelinite, and analcite. Recently, thaumasite was identified in Miocene tuffs from the Mariana Basin and described in detail by Karpoff et al. (1992).

This paper describes the occurrence and the chemical and isotopic composition of thaumasite in basaltic andesite and tuffs from Ocean Drilling Program (ODP) Hole 841B in the forearc region of the Lau Basin. The formation of thaumasite is discussed with respect to host rock alteration and the composition of present-day pore fluids recovered from the thaumasite-bearing sequence.

\section{GEOLOGIC SETTING}

Hole $841 \mathrm{~B}$ is located west of the trench-slope break, approximately $55 \mathrm{~km}$ west of the axis of the Tonga Trench and $60 \mathrm{~km}$ east of the crest of the Tonga Ridge at $23^{\circ} 20.7^{\prime} \mathrm{S}, 175^{\circ} 17.9^{\prime} \mathrm{W}$ in a water depth of $4810 \mathrm{~m}$ (Fig. 1). Drilling at this location was planned to compare the forearc sites drilled in the Bonin and Mariana arc systems during Legs 126 and 129.

Two major igneous sequences were recovered from Hole 841B. The first is a series of basaltic andesite and andesite units $(7 \mathrm{~cm}$ to 17 $\mathrm{m}$ thick), probably sills, occurring between 324.76 and $497.68 \mathrm{~m}$ below seafloor (mbsf) within a thick pile of upper and middle Miocene volcaniclastic sediments (56-549 mbsf). The second sequence, extend-

\footnotetext{
'Hawkins, J., Parson. L., Allan, J., et al., 1994. Proc. ODP, Sci. Results, 135: College Station, TX (Ocean Drilling Program).

${ }^{2}$ Institut für Mineralogie und Lagerstättenlehre der RWTH Aachen. Wüllnerstrasse 2. 52062 Aachen. Federal Republic of Germany.
}

ing from $605.05 \mathrm{~m}$ to the bottom of the hole at $834.20 \mathrm{mbsf}$, comprises a series of low-K rhyolites, rhyolitic tuffs, flow breccias, welded tuffs, and lapilli tuffs. Both igneous sequences are separated by early Oligocene and upper Eocene shallow-water calcareous volcanic siltstones (549-605 mbsf) showing strong evidence for a $>5000-\mathrm{m}$ subsidence since Eocene times (Shipboard Scientific Party, 1992).

\section{ANALYTICAL TECHNIQUES}

The X-ray diffraction (XRD) analyses were made on powdered samples using a Siemens Model D500 diffractometer with a scanning speed of $1 \% \mathrm{~min}$. The samples were run between $2^{\circ}$ and $72^{\circ} 2 \Theta$ at 45 $\mathrm{kV} / 35 \mathrm{~mA}$ using $\mathrm{Cu}-\mathrm{K} \alpha$ radiation. Major and trace elements were determined by X-ray fluorescence (XRF) analysis using a Philips Model PW 1400 spectrometer on a fused glass disc and a pressed powder pellet. Both $\mathrm{CO}_{2}$ and $\mathrm{SO}_{3}$ were determined by means of an infrared spectrometer after inductive volatilization. Instrumental neutron activation analysis (INAA) was used to detect rare earth and other trace elements. Fragments of the vein sample were observed under a JEOL Model JSM6400 scanning electron microscope (SEM) for textural characterization.

\section{RESULTS}

Thaumasite was identified at 325.14 mbsf (Core 135-841B-18R2) filling a $0.5-\mathrm{cm}$ fissure in basaltic andesite (Fig. 2). In addition, thaumasite occurs at $530.30 \mathrm{mbsf}$ (Core 135-84lB-39R-CC) as a component of Miocene volcaniclastic sediments.

The XRD pattern of thaumasite (Fig. 3) from both occurrences correspond to the ASTM-JCPDS powder file and to the d-spacing values of thaumasite published by Knill (1960).

Veins and fractures cross-cutting the basaltic andesite are filled with quartz, analcite, chabazite, and minor carbonate. Locally, sulfides such as pyrite, chalcopyrite, pyrrhotite, and marcasite were identified. A small vein filled with quartz, chabazite, albite (?) and subordinate pyrite, marcasite, and chalcopyrite occurs about $7 \mathrm{~cm}$ above the thaumasite fissure at $325.14 \mathrm{mbsf}$ (Fig. 2). The XRD analysis of a bulk sample of basaltic andesite at $325.28 \mathrm{mbsf}$ yielded analcite as a minor constituent.

Alteration of the Miocene sediments resulted in the formation of fibrous aggregates of natrolite-thompsonite and bladed prehnite in pore spaces. Locally, analcite was found to replace plagioclase, and in some cases, pumice shards are replaced by heulandite (?).

Scanning electron microscopy of the fissure thaumasite indicates well-crystallized material with compact prismatic habit (Fig. 4). Chemical analyses and formula calculations exhibit a composition very close to the theoretical formula (Table 1). Only minor amounts 


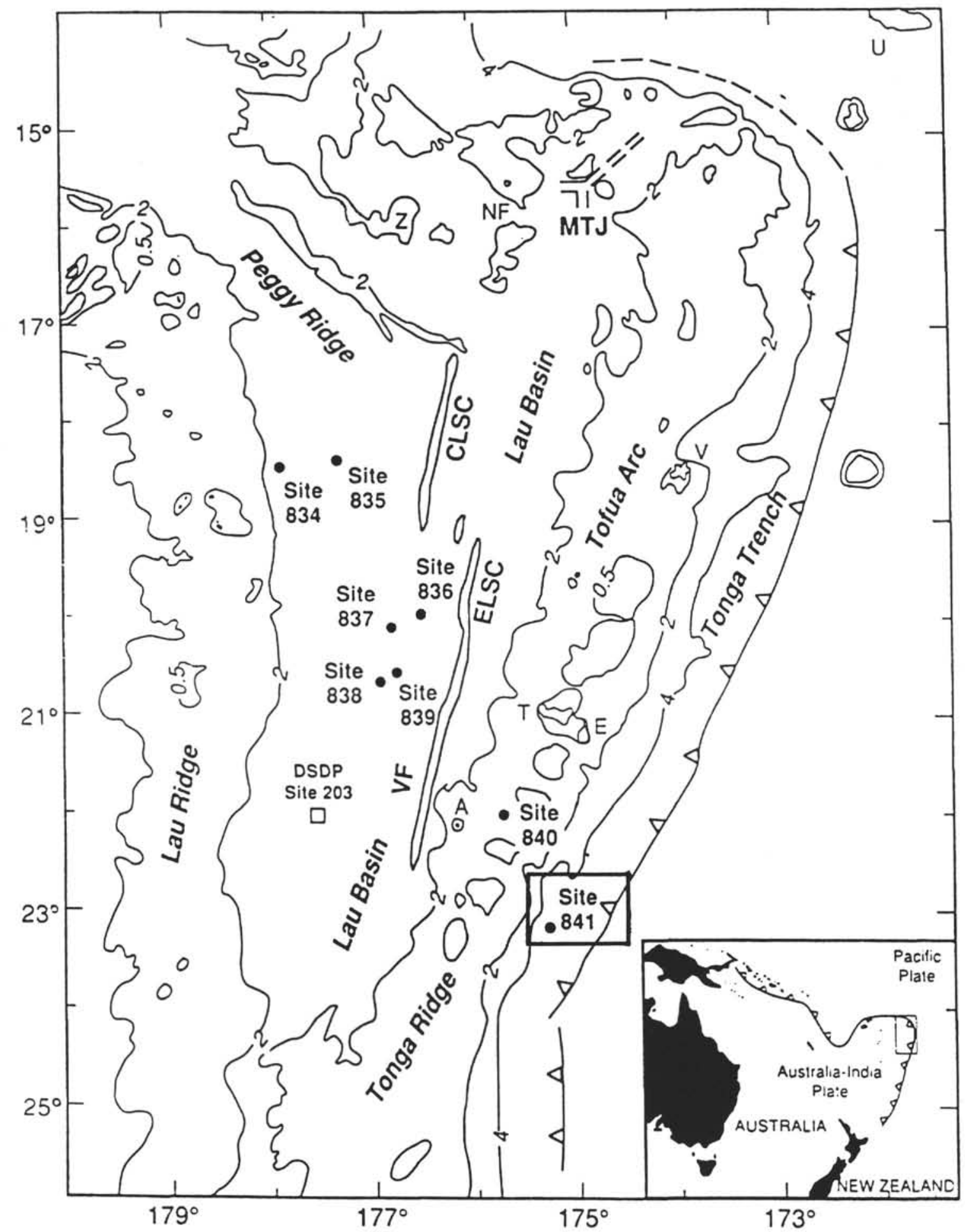

Figure 1. Location map of Sites 834-841 in the Lau Basin and Tonga Trench system. Bathymetry in kilometers. Locations of the Central and Eastern Lau spreading centers, the Valu Fa Ridge, and the Mangatolu Triple Junction are shown as CLSC, ELSC, VF, and MTJ, respectively. Islands include $\mathrm{Z}=\mathrm{Z}$ ephyr Shoal, $\mathrm{NF}=$ Niuafo' $\mathrm{ou}, \mathrm{V}=$ Vava' $\mathrm{u}, \mathrm{T}=$ Tongatapu, $\mathrm{E}={ }^{\prime} \mathrm{Eua}, \mathrm{A}=\mathrm{A}$ ta, and $\mathrm{U}=\mathrm{Upolu}$.

of $\mathrm{Al}, \mathrm{Fe}, \mathrm{Mg}$, and $\mathrm{Na}$ were detected. With the exception of $\mathrm{Br}(18$ $\mathrm{ppm})$, all trace elements measured are below or close to the detection limits of XRF and INAA.

Sulfur isotope ratios of two thaumasite separates are $+23.5 \%$ and $+21.1 \% 0 \delta^{34} \mathrm{~S}$, which is close to the sulfur isotope composition of seawater sulfate $(+21.0 \%$; Rees et al., 1978).
Interstitial waters recovered from the thaumasite-bearing sequence are characterized by high concentrations of $\mathrm{Ca}^{2+}(5,700 \mathrm{ppm})$ and $\mathrm{Cl}^{-}$ $(23,000 \mathrm{ppm})$ and thus represent $\mathrm{CaCl}_{2}$-rich brines. Sulfate and $\mathrm{Na}^{+}$in these fluids decrease from seawater level to $1000 \mathrm{ppm} \mathrm{SO}_{4}^{2-}$ and 8,000 ppm $\mathrm{Na}^{+}$and concentrations of $\mathrm{Mg}^{2+}$ and $\mathrm{K}^{+}$drop toward zero. The $\mathrm{Si}^{4+}$ concentration decreases from about 17 to $<4 \mathrm{ppm}$. 


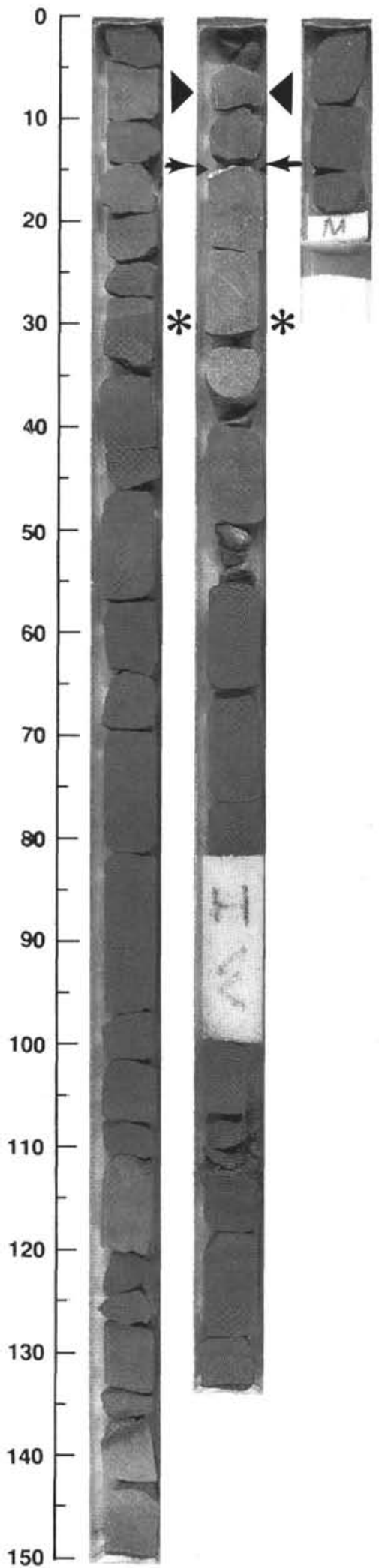

Figure 2. Photograph of Core 135-841B-18R (323.5-333.2 mbsf) with thaumasite (arrows) filling a fracture in basaltic andesite at 325.14 mbsf (Section 135-84IB-18R-2, 14-15 cm). The thin vertical vein in Section 135-84IB-18R$2,7-10 \mathrm{~cm}$ (triangles) contains quartz, analcite, chabazite, and sulfides. Analcite and quartz (asterisks) were detected by XRD in Sample 135-84IB$18 \mathrm{R}-2,28-32 \mathrm{~cm}$.
Table 1. Determined and theoretical (in brackets) chemical composition of thaumasite $\left[\mathrm{Ca} 3 \mathrm{Si}(\mathrm{OH})_{6} \cdot 1_{2} \mathrm{H}_{2} \mathrm{O}\right]\left(\mathrm{SO}_{4}\right)$ $\left(\mathrm{CO}_{3}\right)$, Hole 841B (325.14 mbsf).

\begin{tabular}{|c|c|c|c|c|c|c|}
\hline \multicolumn{3}{|c|}{ Major elements (wt\%) } & \multicolumn{4}{|c|}{ Trace elements (ppm) } \\
\hline $\mathrm{SiO}_{2}$ & 9.80 & $(9.65)$ & Sc & 0.2 & $\mathrm{Sb}$ & $<0.2$ \\
\hline $\mathrm{TiO}_{2}$ & $<0.01$ & & $\mathrm{Cr}$ & 2 & $\mathrm{Cs}$ & $<1$ \\
\hline $\mathrm{Al}_{2} \mathrm{O}_{3}$ & 0.30 & & Co & 1 & $\mathrm{Ba}$ & $<50$ \\
\hline $\mathrm{Fe}_{2} \mathrm{O}_{3}$ & 0.05 & & $\mathrm{Br}$ & 18 & $\mathrm{Hf}$ & $<0.5$ \\
\hline $\mathrm{MnO}^{2}$ & $<0.01$ & & $\mathrm{U}$ & 0.5 & $\mathrm{Ta}$ & $<1$ \\
\hline $\mathrm{MgO}$ & 0.03 & & $\mathrm{Ni}$ & $<20$ & w & $<3$ \\
\hline $\mathrm{CaO}$ & 27.41 & (27.02) & $\mathrm{Zn}$ & $<20$ & Th & $<1$ \\
\hline $\mathrm{Na}_{2} \mathrm{O}$ & 0.12 & & As & $<2$ & $\mathrm{La}$ & $<0.5$ \\
\hline $\mathrm{K}_{2} \mathrm{O}$ & $<0.05$ & & $\mathrm{Se}$ & $<3$ & $\mathrm{Ce}$ & $<3$ \\
\hline $\mathrm{P}_{2} \mathrm{O}_{5}$ & $<0.05$ & & $\mathrm{Rb}$ & $<10$ & $\mathrm{Nd}$ & $<5$ \\
\hline $\mathrm{SO}_{3}$ & 13.12 & $(12.86)$ & $\mathrm{Sr}$ & $<10$ & $\mathrm{Sm}$ & $<0.1$ \\
\hline $\mathrm{CO}_{2}$ & 7.69 & $(7.07)$ & Mo & $<5$ & Eu & $<0.2$ \\
\hline \multirow[t]{2}{*}{$\mathrm{H}_{2} \mathrm{O}$} & 42.00 & $(43.40)$ & $\mathrm{Ag}$ & $<5$ & Tb & $<0.5$ \\
\hline & & & $\mathrm{Cu}$ & $<20$ & $\mathrm{Yb}$ & $<0.2$ \\
\hline \multirow[t]{5}{*}{ Total } & 100.52 & & $\mathrm{Nb}$ & 10 & $\mathrm{Lu}$ & $<0.05$ \\
\hline & & & $\mathrm{Zr}$ & $<20$ & & \\
\hline & & & $\mathrm{Y}$ & $<10$ & {$[\mathrm{ppl}$} & \\
\hline & & & $\mathrm{Ga}$ & $<10$ & $\mathrm{Au}$ & $<5$ \\
\hline & & & $\mathrm{Co}_{0}$ & $<20$ & Ir & $<20$ \\
\hline
\end{tabular}

Formula calculation on the basis of

\begin{tabular}{lcc} 
& 25 O-atoms & \\
\cline { 2 - 2 } $\mathrm{Si}$ & 1.019 & $\mathrm{Si}, \mathrm{Ca}, \mathrm{Na}, \mathrm{K}, \mathrm{S})=5$ \\
$\mathrm{Al}$ & 0.036 & 0.995 \\
$\mathrm{Fe}$ & 0.004 & 0.035 \\
$\mathrm{Mg}$ & 0.004 & 0.004 \\
$\mathrm{Ca}$ & 3.053 & 0.004 \\
$\mathrm{Na}$ & 0.024 & 2.981 \\
$\mathrm{~S}$ & 1.024 & 0.023 \\
$\mathrm{C}$ & 1.091 & 1.000 \\
$\mathrm{OH}$ & 6.112 & 1.066 \\
$\mathrm{H}_{2} \mathrm{O}$ & 11.520 & 5.968 \\
\hline
\end{tabular}

\section{DISCUSSION}

The occurrence of thaumasite together with zeolites (analcite, natrolite-thompsonite, heulandite [?]), prehnite, and sulfide-bearing quartz-chabazite veins characterizes alteration in the upper part of the volcanic sequence of Hole $841 \mathrm{~B}$. This assemblage is similar to that described by Noack (1983) and Karpoff et al. (1992). Experimental data by Abe and Aoki (1976) indicate that analcite is formed at temperatures of $150^{\circ}-160^{\circ} \mathrm{C}$, whereas chabazite is thought to form below $80^{\circ} \mathrm{C}$ (Karpoff et al., 1992).

According to Giampaolo (1986), the upper thermal stability limit of thaumasite does not exceed $60 \pm 5^{\circ} \mathrm{C}$. At higher temperatures, thaumasite readily decomposes to calcite and gypsum. Giampaolo (1986) stated that thaumasite can be considered as an index mineral for low-enthalpy geothermic conditions.

Pore fluids recovered from the thaumasite-bearing interval are among the most intensively modified pore waters of seawater origin. The presence of $\mathrm{CaCl}_{2}$-rich fluids seems to support the formation of thaumasite, as indicated by samples of thaumasite from the Mariana Basin (Site 802, Leg 129), where almost identical $\mathrm{Ca}^{2+}$ and $\mathrm{Cl}^{-}$ concentrations $\left(5,200 \mathrm{ppm} \mathrm{Ca}^{2+}\right.$ and $\left.22,200 \mathrm{ppm} \mathrm{Cl}^{-}\right)$were found in the pore fluids (Larson, Lancelot, et al., 1992). Similar $\mathrm{CaCl}_{2}$-rich brines $\left(12,000 \mathrm{ppm} \mathrm{Ca}^{2+}\right.$ and $\left.25,200 \mathrm{ppm} \mathrm{Cl}^{-}\right)$were collected during Leg 126 in the Bonin Arc (Taylor, Fujioka, et al., 1992), but no indications for the occurrence of thaumasite are reported.

The changes in the concentrations of $\mathrm{Ca}^{2+}, \mathrm{Mg}^{2+}, \mathrm{K}^{+}$, and $\mathrm{Na}^{+}$at Site 841 are much more pronounced than usually observed in porewater-depth profiles. The composition of these pore waters might be explained by the intensive interaction of seawater with volcanic material. It is assumed that diffusive exchange of the fluids with bottom seawater was limited by a high rate of volcaniclastic sedimentation and allowed to maintain a steep gradient in concentration. The elevated $\mathrm{Cl}^{-}$concentrations are probably caused by the hydration of primary minerals under these conditions.

Thaumasite from 325.14 and $530.30 \mathrm{mbsf}$ has $\delta^{34} \mathrm{~S}$ values of $+23.5 \%$ and $+21.1 \%$. These values are almost identical to seawater 
and suggest only insignificant sulfur isotope fractionation during the formation of thaumasite. Reported $\delta^{34} \mathrm{~S}$ ratios for Site 802 thaumasite samples from the Mariana Basin $(+20.4 \%$ and $+19.5 \%$; Alt and Burdett, 1992) are similar to those of interstitial water $(+20 \%$ to $+28 \% 0 \delta^{34} \mathrm{~S}$; Alt and Burdett, 1992), indicating seawater as the source of sulfur. The influence of seawater during the formation of thaumasite is also indicated by an elevated $\mathrm{Br}$ content (i.e., $18 \mathrm{ppm}$ ). In addition to seawater, part of the $\mathrm{Ca}$ and $\mathrm{Si}$ in thaumasite might have been supplied by the alteration of plagioclase to analcime.

\section{CONCLUSIONS}

Thaumasite in altered volcanics of the Lau Basin forearc is considered to be a product of low-temperature hydrothermal fluids that are identical in composition to those presently circulating in the subseafloor. These fluids are of seawater origin and have achieved high concentrations of $\mathrm{Ca}^{2+}$ because of their limited exchange with bottom seawater. Fluid temperatures from $<80^{\circ}$ to $>150^{\circ} \mathrm{C}$ are documented by the presence of analcite, chabazite, and $\mathrm{Fe}$ - and $\mathrm{Cu}-$ sulfides. The upper thermal stability limit of thaumasite $\left(60^{\circ} \pm 5^{\circ} \mathrm{C}\right.$; Giampaolo, 1986), however, indicates a late-stage formation at lowtemperature conditions.

\section{ACKNOWLEDGMENTS}

This work was supported by the German Research Foundation (DFG Grant He 1660/4). Thanks are due to Anne-Marie Karpoff and Gustaf Arrhenius for their constructive comments on the manuscript.

\section{REFERENCES}

Abe, H., and Aoki, M., 1976. Experiments on the interaction between $\mathrm{Na}_{2} \mathrm{CO}_{3}-$ $\mathrm{NaHCO}_{3}$ clinoptilolite tuff, with references to analcimization around Kurokotype mineral deposits. Chem. Geol., 17:89-100.

Alt, J.C., and Burdett, J.W., 1992. Sulfur in Pacific deep-sea sediments (Leg 129) and implications for cycling of sediment in subduction zones. In Larson, R.L.. Lancelot, Y., et al., Proc. ODP, Sci. Results, 129: College Station. TX (Ocean Drilling Program). 283-294.
Giampaolo, C., 1986. Dehydration kinetics of thaumasite at ambient pressure. Neues Jahrb. Mineral. Monatsh., H3:126-134.

Grubesi, O.. Mottana, A., and Paris, E., 1986. Thaumasite from the Tschwinning Mine, South Africa. TMPM. Tschermaks Mineral. Petrogr: Mitt., $35: 149-156$.

Hentschel, G., 1979. Hydrothermale Minerale im Basalt von Ortenberg (Vogelsberg). Geol. Jahrb. Hessen, 107:193-196.

Heritsch, H., 1988. Thaumasit von Klöch. Oststeiermark: Röntgendaten, chemische Analyse und optische Konstanten. Mitt. Naturwiss. Ver. Steiermark, 118:89-94.

Karpoff, A.M., France-Lanord, C., Lothe, F., and Karcher, P., 1992. Miocene tuff from Mariana Basin, Leg 129, Site 802: a first deep-sea occurrence of thaumasite. In Larson, R.L., Lancelot, Y., et al., Proc. ODP, Sci. Results, 129: College Station, TX (Ocean Drilling Program), 119-135.

Knill. D.C., 1960. Thaumasite from Co. Down, Northern Ireland, Mineral. Mag., 32:416-418.

Larsen. E.S., and Dunham, K.C., 1933. Tilleyite, a new mineral from the contact zone at Crestmore, California. Am. Mineral., 18:469-473.

Larson, R.L., Lancelot, Y., et al., 1992. Proc. ODP, Sci. Results, 129: College Station, TX (Ocean Drilling Program).

Noack. Y., 1983. Occurrence of thaumasite in a seawater-basalt interaction. Mururoa atoll (French Polynesia, South Pacific). Mineral. Mag., 47:47-50.

Nordenskiöld, A.E.. 1878. Sur une nouvelle espèce minérale nommée thaumasite. C. R. Acad. Sci. Ser. 2, 87:313-314.

Rees, C.E., Jenkins, W.J., and Monster, J., 1978. The sulphur isotopic composition of ocean water sulphate. Geochim. Cosmochim. Acta, 42:377-381.

Shipboard Scientific Party, 1992. Site 841. In Parson, L., Hawkins, J., Allan, J., et al., Proc, ODP. Init. Repts., 135: College Station, TX (Ocean Drilling Program), 571-677.

Taylor, B., Fujioka, K., et al., 1992. Proc. ODP, Sci. Results, 126: College Station, TX (Ocean Drilling Program).

Vogt. T., 1938. Thaumasite from Sulitelma, Norway. Norsk. Geol. Tidsskr., 18:291-303.

\footnotetext{
Abbreviations for names of organizations and publication titles in ODP reference lists follow the style given in Chemical Abstracts Service Source Index (published by American Chemical Society).
}

Date of initial receipt: 6 July 1992

Date of acceptance: 30 March 1993

Ms 135SR-128

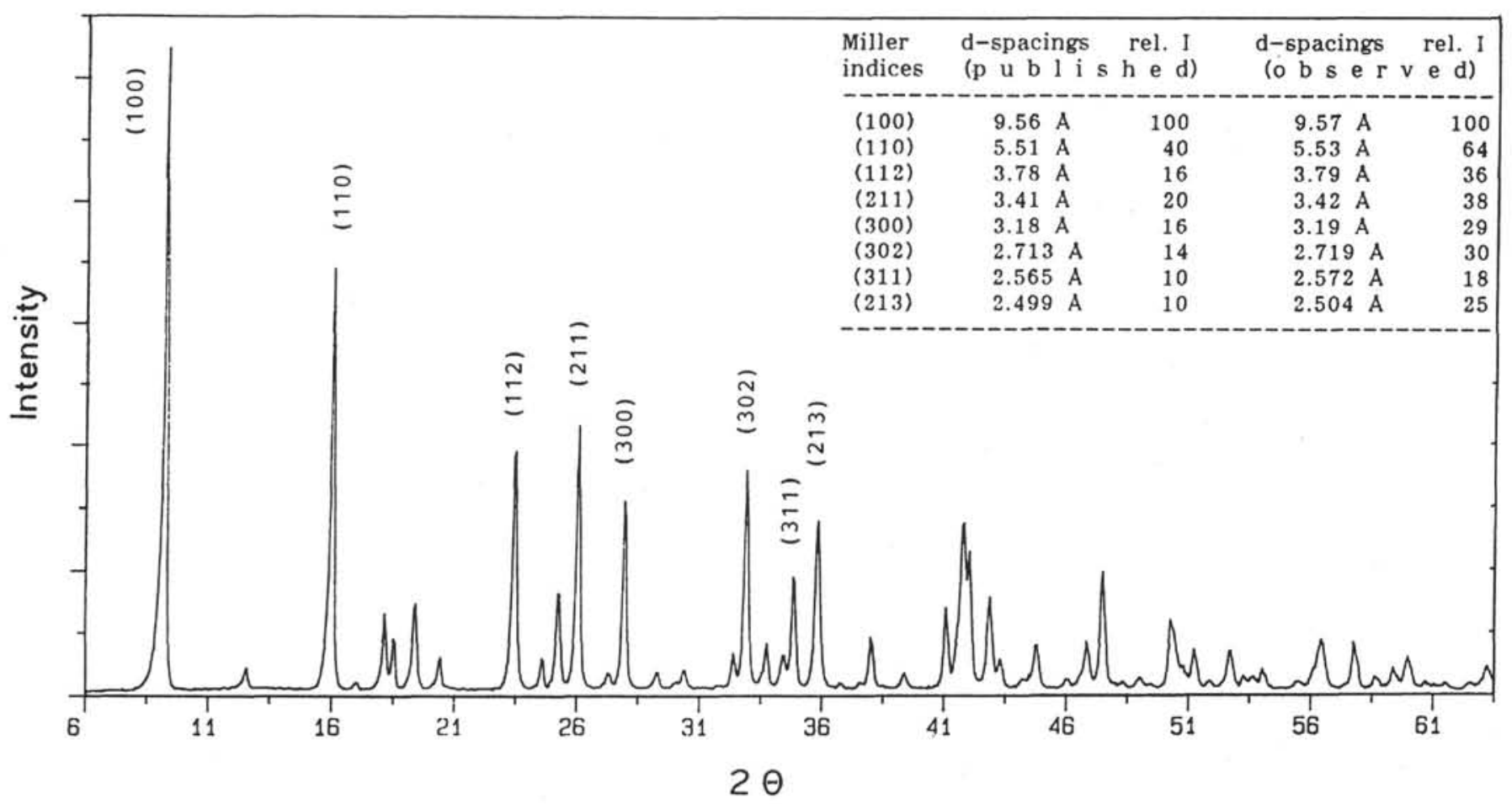

Figure 3. The XRD pattern of thaumasite $\left[\mathrm{Ca}_{3} \mathrm{Si}(\mathrm{OH})_{6} \cdot 12 \mathrm{H}_{2} \mathrm{O}\right]\left(\mathrm{SO}_{4}\right)\left(\mathrm{CO}_{3}\right)$ from Sample $135-841 \mathrm{~B}-18 \mathrm{R}-2,14-15 \mathrm{~cm}(325.14 \mathrm{mbsf})$ with data of published and observed $d$-spacings and relative intensity. 
A

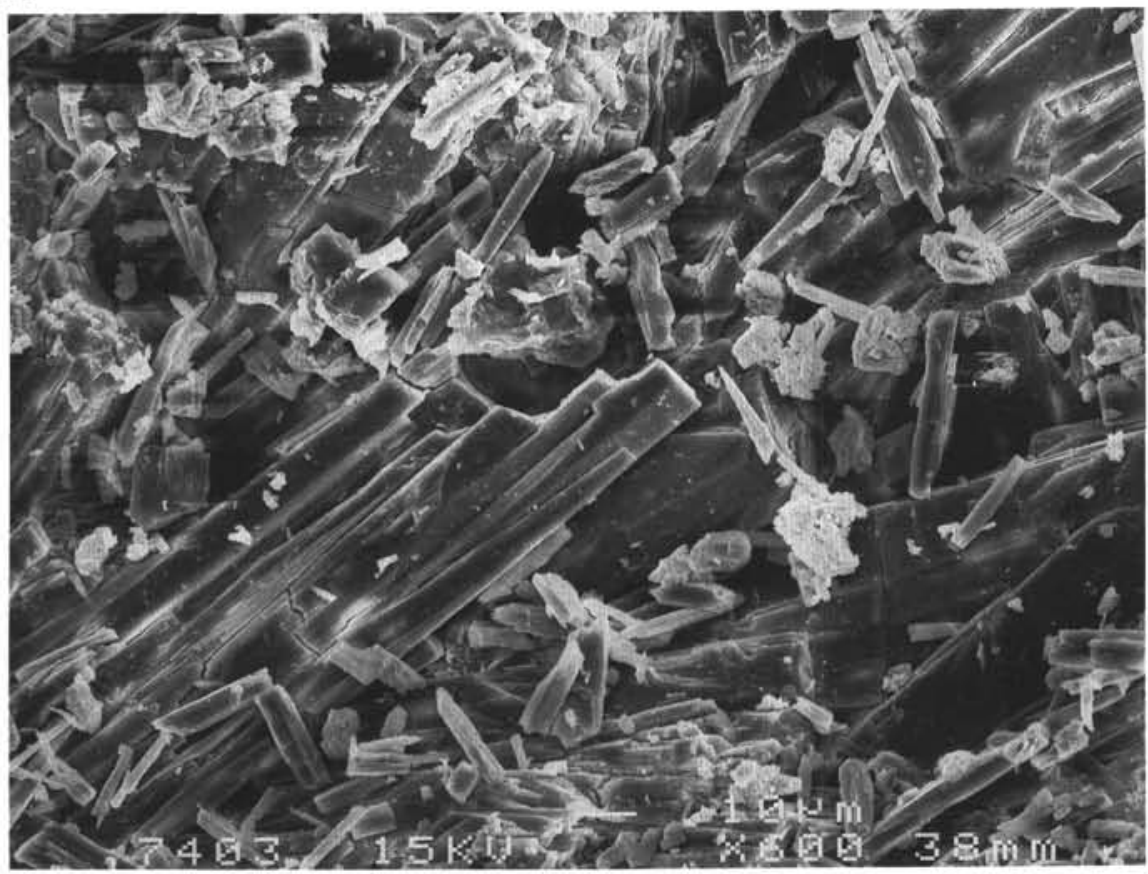

B

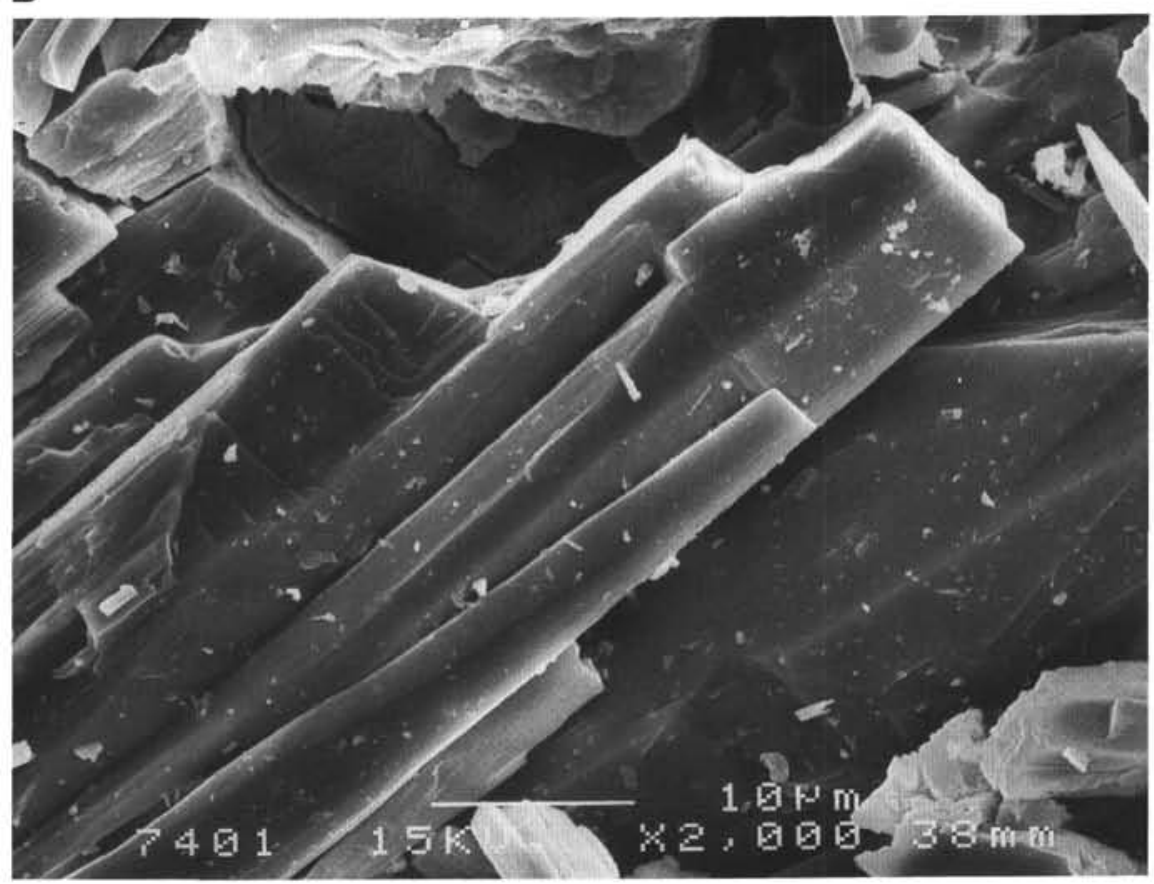

Figure 4. A. Scanning electron photomicrograph of fracture-filling thaumasite from Hole 841B (Sample 135-841B-18R-2, 14-15 cm). B. Close-up of the same sample showing typical prismatic habit of thaumasite. 